\title{
To Review and Analyze Thoughts and Political Ideas of Muhammad Abduh and Ali Abd al-Raziq
}

\author{
Zahra Navabzadeh $^{1} \&$ Aliakbar Amini ${ }^{1}$ \\ ${ }^{1}$ Department of Private Law, Zahedan Branch, Islamic Azad University, Zahedan, Iran \\ Correspondence: Zahra Navabzadeh, Department of Private Law, Zahedan Branch, Islamic Azad University, \\ Zahedan, Iran. E-mail: Zahra.navabzadeh2014@gmail.com
}

Received: June 28, 2016 Accepted: July 24, 2016 Online Published: November 30, 2016

doi:10.5539/jpl.v9n10p163 URL: http://dx.doi.org/10.5539/jpl.v9n10p163

\begin{abstract}
Flows of recent Islamic awakening which changed a number of Islamic countries, this question is arisen that theoretical background of this movement should be looked at in whose thought and action. In response to this, according to the forefront of Egypt during the last two centuries, minds are directed toward Mohammad Abduh and Ali Abd al- Raziq. Muhammad Abduh and Ali Abdel are among the leaders and thinkers of the Islamic awakening in the Sunni world. Both, with common but differentiated pain about Muslim countries condition, backwardness and have been holding back their countries, had a think and they believed Islam was the final choice and tried to offer solutions in these areas that their solutions, according to performance and attitude, are notable. Therefore, the implementation of the political ideas of these two influential thinkers in the Muslim world is important. As far as studies show that, despite the great works of thought and ideas of these two scientists have been published, but no comparative studies have been discussed. Thus, due to the importance of the issue, so comparatively in this article, these two scholars of Islam world have been studied.
\end{abstract}

Keywords: political thought, government, secularism, Abdu al-Raziq, Abdu

\section{Introduction}

One of the indicators in Islam and the Prophet is establishing the theocracy and to verify the interaction of religion with politics. Historical facts indicate that the goals of God revolution and great reformation of Prophet has made possible in the light of the establishment of the theocracy. But despite the historical fact and explicit Sire of the prophet's theocracy, Muhammad, some scholars have tried to confirm the thesis of "separation of religion and government" or "religion interacts with politics and not with the government," and pay attention to the distinction between prophecy and the prophet government, and deny this obvious fact or justify it by means of all kinds of interpretations and commentaries. No doubt that the necessity of establishing a government is one of the requirements of human intellect that most divine and non-divine schools have the necessary stamp of approval on it. The human needs for social life and the need for security and the division of labor had not realized with no executive and the legislature. Thus, the society need for social order and the establishment and management are obvious issues the scholars and thinkers; just as the historical and sociological and anthropological reports, all suggest that human societies had never been empty of government institutions, leadership and political and social management. In fact, for this to prevent chaos and conspiracy against the security of society, the need to establish an institution called government, that the power is adequate, it is necessary to accomplish social organization. Islam is a religion that has the most complete and the most favorable legal system that is valid until doomsday, claiming that for all the dimensions and aspects of personal and social life of all men, in all ages, there are rules and regulations. Such a religion can never know government urgently needed. Then it is decisively proven that Islam has provisions for government either and also considers it necessary for the Muslim community and it does not need for devotional evidence. Even if a verse or a story about this was not a problem, we had no problem. Of course, there is also devotional reason that should be studied in jurisprudence, but we should not neglect the decisive reason. There is no doubt that Islam considers necessary the government for the Muslim community. The possibility that this religion denies the necessity of government religion or even is quiet about it is completely dead. So the principle of this issue is one of the definitive certainties of this sacred religion of Islam. If there is a discussion about the quality of governance and how to determine and governor and his duties and powers, so that this should be known by referring to the Quran 
and finality principle.

\section{Problem Statement}

With the recent Islamic Awakening movements which changed a number of Islamic countries, this question is arisen that theoretical background of this movement should be looked in whose thought and action. In response to this, according to the forefront of Egypt during the last two centuries, attention is directed toward Muhammad Abduh and Ali Abd al-Raziq. Muhammad Abduh and Ali Abdel Raziq are among the leaders and thinkers of the Islamic awakening in the Sunni world. Sheikh Muhammad Abduh (1848- 1905) was an Egyptian empowerment scientist, awake and great reformer who was strongly influenced by his teacher, Sayyid Jamal al-Din. He was among the few people in Sunni who stood up against the fanaticism and extreme rigidity of his time and the onslaught of the West culture to the honor of Islam and presented many scientific works to Muslim community. He could water the great thinkers in science and proved that Islam is not opposed to development, but it is also a promoter of knowledge, thought and intellection either; and emphasized that the current situation of Muslims is result of Muslims separation from Islam, Islam is not disabled. Sheikh Muhammad Abduh never spoke about a separation between religion and politics and did not believe it either. He liked the government things are done on the basis of consultancy with people and believed that the Muslim ruler must comply with Islamic law and consult with those who capture the resolution and contract to justice. Because of the concern of reformers and Islamic unity, Sheikh Muhammad Abduh, despite belonging to the Egyptian community, in terms of political and religious ideas, has obtained transnational and religious reputation. Unlike Muhammad Abduh, Ali Abdel-Raziq believed in the separation of religion and government and knew government as human, independent and severed affair from religion that receives its legitimacy and truth from public assembly and this human legitimacy is so much absolute and strong upon which even the legitimate government has revocation License and abrogation of Sutra of Messenger of Allah and it is also inventedan alternative. Abdul, repeatedly in his book (Islam and the foundations of power), lays his finger on the issue that Islam has not given any definite form for the political system and has left it on the human intellects and experiences; and choose the best type of political system to meet their interests and expedients based on the circumstances of their own time. It can be said in the importance of his thinking that still, after over several decades of the life of his major work, "Islam and the foundations of power," political thought in the Arab and Islamic world is in conversation with him. His book is so outstanding that no researcher and expert on Islamic thought can pass along it indifferently so that we can say secular thinkers have not brought more than his words after him. Abduh and Abdal-Raziq were following different two thoughts. One had been thought to the implementation of Islamic law and another in emphasizing the use of human assets in government. Thus, the implementation of the political ideas of these two influential thinkers is important in the Muslim world. As far as studies show that, despite the great works of thought and ideas of these two scientists have been published, but nobody has not discussed them in any comparative study. Thus, due to the importance of the issue, so comparative in this article, these two Islam scholars have been studied.

\section{Islamic Awakening}

Islamic Awakening is a social phenomenon that means to return to their awakening and vigilance of the Muslim nation to achieve self-esteem and to pride their religion, dignity and political, economic and intellectual independence and attempt in order to fulfill its role as "the best nation for the people " (Yazdanpanah, 2011: 348). Napoleon's expedition to Egypt caused the awakening of the Muslim world from his centuries of sleep. Although this outcome had somewhat active role in awakening the Islamic world, this was only its positive procedure. On the other hand, it is also important and it was western governments' receive and their easy access to the lands of Islam, the Ottoman Empire. Thus, positive aspect of this invasion was to foster Islamic awakening in the last quarter of the nineteenth century which was begun by Syed Jamal al-Din Asadabadi. However, confronting the West had been started before him. In this process, Muhammad Abduh, Rashid Reza and others entered Islamic movement fights scene (Maqsoodi and Heidari, 2011: 43).

\section{Different Approaches of Political Thought in Islam}

\subsection{Philosophical Approach}

The first approach to the study of this Political Thought is in Islam philosophical approach that shapes "political philosophy" combination. Political philosophy definition presents "political philosophy is to research on issues of public life and to advance its quality" (Strauss, 1996: 5). Political philosophy often deals in an abstract manner with the government purposes and appropriate tools to achieve them and the best form of government. The main topics of political philosophy include topics such as how to obtain truth, justice, principles of the common good, freedom and equality requirements, to base political life on moral principles, reason and necessity of government, adherence reasons of power and its components. Political philosophy consists of two main parts: one is 
descriptive issues and other is prescription topics and how to ensure political ends (Bashiriyeh, 1997: 17).

\subsection{Theological Approach}

The second approach considered in the political ideas of Islam is theological approach that forms "political theology" combination. Politically speaking, the subject of political theology is "act of God", the act is related to politics issues and to administer and resolve them. Since the beginning of the rise of Islam, the leadership and the pontificate has been always considered by Muslims and, after the death of the Prophet of Islam, this issue became a great dispute among Islamic sects. Fissures and differences arising from the Saqife-Bani Saede incident escalated tensions among al-Qahtani, Adnan, Ansar and Mohajer Arabs and the intensified Quraish infighting and caused the loss of Hadithes integrity and traditions of the Prophet and were offered different interpretations. The formation of movements and political challenges within the Muslim community caused the emergence of theological schools, Mu'tazila and Ash'arite. . For example, the murder of Osman raised several issues, including whether the murderers of Othman were right or not? Do Osman actions, in the event of an error, renounce his faith and what actions will lead to the elimination or consolidation of faith? Or what was the situation in the Battle of the Camel, on the one hand, Imam Ali was (as), and on the other hand, Ayesha, the wife of the Prophet (pbuh) and Talha and Zubayr of the companions of the Prophet (PBUH)? Do they know Imam Ali (as) a superior person or act on his own judgment? These issues and other issues led to the formation of political-theological opinions or political theology among the Muslim (Ghaderi, 1999: 7-5). In general, it should be noted that, contrary to jurisprudence, which dates back to the minutiae of religion, theology refers to the principles of religion and proposes its major political debate about the grace of God, leadership, Imamat, caliphate, purity, appointment, role of the people, algebra, freedom , rational good and evil, inherent beauty and ugliness (Javadi Amoly, 1989: 78).

\subsection{Jurisprudence Approach}

The third approach considered is jurisprudence approach of political thought in Islam that has formed "political jurisprudence" compound. Literally, jurisprudence means absolute understanding or accurate understanding of theoretical issues; or sparingly, knowing knowledge of religious subsidiary orders based on their detailed evidence. So Fiqh is not absolute knowing of orders, but it is the knowing reasoning of orders, i.e., to know based on the reasons and means of proof not means in fixation (Gorji, 1996: 7). The purpose of political fiqh is jurisprudence normative set of responses to political issues. Normality is common feature of political jurisprudence and political philosophy, but as it was said, "reasoning" is the basis of political philosophy, whereas the basis of political jurisprudence is "devotion". In the Middle Ages, attitude of jurisprudence (legal) to policy was introduced in the West by Aquinas and St. Augustine of Hippo. In Islam, as well as by integrity in various fields, laws and ordinances have been enacted with the aim of achieving human well-being (Ashtar aus, 1994: 36). Major political jurisprudence debates and issues are surrounding the Jihad, enjoining good and forbidding wrong, Hesba, tribute, Fy', property, rulings of the sultan, the provinces, and especially the supreme leader that Shia and Sunni scholars and jurists debated and did research in these fields (Amid Zanjani, 1994: 19).

\subsection{Mystical Approach}

The fourth approach in Islamic political thought is mystical approach that can be used with a tolerance of "political spirituality" combination. Sufism means the theology by the heart and the love of worshiping God. Mysticism has chosen a middle way in dealing with the origin of the material school that the believes in this universe truth, and the school of thought authenticity that believes in lack of inherent dignity of the outside world and the imagination originality of human subjective meanings around the outside world; thus, it admits the senses perceptions that the world practical knowledge would emerge from it and considers it as illustrator power. But it believes in a universe of causes that is beyond the senses and also knows it has a truth superior than sensory reality of the world. However, compared with the Qoosavi truth, that is, the truth of God, more than anything else, it looks like an unstable mirage. Confess to the world of sense in mysticism, is essential for the wayfaring man because men are alive, they live in this sensible world and establish their behavior compared with that. Therefore, mysticism means a system of consistent votes based on personal experience and intuition of human existence going beyond conventional wisdom and entrust ways to the universe truth and discovering the relationship between the human with God and God's creations, in the framework of the "supervision of all absolute divine" and requiring its parts (Qesari Roomi, Mohammad Dawood, 1996: 345).

\section{Research Methodology}

This research is analytical-descriptive in terms of goal. In this regard, this paper is to review and criticize the opinions and political ideas of Muhammad Abduh and Ali Abdal-Raziq about Islamic government. 


\section{Research Findings}

Theory of the consociation between religion and politics in Islam

Most Muslim thinkers believe that establishing government by the Prophet Muhammad in Medina is considered a part of his prophetic mission. Although Muslims do not stipulate this (because questions have been raised this ratio to them), but accepting this consociation had been at the core of all branches of Islamic political thought, sects and religious trends. In the meantime, only a handful of people and movements, most Muslims are a firm believer in the necessity of forming a government in Islam after the Prophet's death (Qaderi, 1996, 39). Among People opposed to the government establishment in Islam, we can note "Abu Bakr asem" and "Hisham Footi," which both had congenial Mu'tazili. Also in this regard, it should be noted to some of the Khawarij denied the government totally that the two sects "Azarqh and Asfarieh" are specifically notable (Ashary Qomi, 2003). Major Sunnis, with an emphasis on government as the caliphate of the Prophet, put emphasis on the relationship between religion and politics in Islam. According to them, the Prophet was responsible for the formation of government and religion orders implementation on the basis of divine message. So his successor is obliged to continue this procedure. The others are followers of rational requirement for government. The major Shiite and Muslim philosophers fit in this group. Most Shiites consider Islamic state establishment a crucial requirement of Islam and know it as wisdom obligatory. Shiites believe in the opening of Immamat based on principle of grace after the finality of prophethood. Except for some periods and for some Shiite currents, concept of supervision is always associated with the Shiites political charge by Imam (Modaresi Tabatabaee, 1995: 13).

\section{The Causes of the Idea of Prophethood Separation from Government}

Not only doubt and hesitation in establishing an Islamic state by the Prophet or reject it is examined from intellectual angle and neglect the other elements; because there is much evidence that the, especially after the Islamic Revolution of Iran, prejudices, missions, ignorance and sometimes hands behind colonialism and despotic rulers of Islamic countries have great impact to design and promote this idea. So a lot of these writings, over irrationality and content less are accompanied with mixed with bitterness and insults and different accusations. Apart from these elements, if we want to analyze these positions, we must say what motivations involved in these currents are superficiality and one-dimensional look to Islam and the Holy Prophet's mission. Another factor that have made some analysts believed to the idea of separation of the prophecy from the government, is to compare the Islamic government at time of the Prophet (PBUH) with today's modern states, while the Prophet's Islamic government should not be structurally compared with today's governments and objectively fundamental distinction exists between the two governments. The fascination of some of these people to the modern state has led that the state government, they do not know the Prophet government which was simple as a state, besides that, the ruling structure of the Prophet might have the most qualified discipline at that time and in no way complex discipline of modern states was not the competence of Islamic government of the Prophet. Furthermore, we should add the frustration of some of these theorists from Ottoman rule on the mentioned causes above. A number of people mentioned criticized Ottoman government performance and governments before it was set up in the name of religion. Rather than splitting it between their performance and Islam, they resorted to secularism and prophecy from the government. Ali Abdel writes: "If we ignore the caliphates and one or two other caliphs, the caliphate has been always associated with violence, domination, oppression. Thus, the caliphate, except war, bloodshed, social losses, has not another benefit to Muslims, was the friendship of caliphate caused Yazid having the Hussein's blood on his hands, son of Fatima, daughter of the Prophet, and led him to attack Medina and destroy its sanctity? (Abdul Raziq, 1998: 75).

\subsection{Ali Abdel Discourse; The Abolition of the Caliphate and Secularism}

Ali Abd al-Raziq is one of Egypt's Muslim thinkers in the 20th century who is known by his theory about secular Islam and rejection of caliphate; something that was contrary to the dominant discourse in the Muslim world and thus it faced with excommunication, trial and violent collisions. Although it cannot be known the historical and geographical conditions of Egypt as well as his position in the escalation of this conflict for him to be ineffective, but its subject and text precision and tone effect is also significant. Relatively short text without the author's definitions and explanations on assumptions that would increase the risk of misunderstanding. Influence of this book can be studied in several ways: First, the formation of Muslim Brotherhood movement that took place three years after its release, a movement wants a return to the early Islamic era, second, provided the context in which created an Islamic extremist currents. One of these characters is Sayyid Qutb who, when Abdul was 35, his book was published, only was 19 years old and so he was in the course of his literary and non-Islamic ideas. However, many commentators believe this book affect as representative of religious modernism on the formation of extremist and fundamentalist currents. According to discourse look, we should see Abdul mind based on what 
semantic formulation is drawn toward the separation of religion from politics, in what structure of spatial arrangement have his ideas formed that has brought him to this point, what had been his main concern or fundamental question in the book " Islam and the principles of Al-Hakam "? Since the perception of concepts, themes and issues of the world within distinct discourses is different, first, it is necessary to know Abdul al-Raziq's discourse to understood discursive space in which he live,. Certainly, his discourse difference has led him to the other reading of the caliphate, Quranic concepts and the relationship between religion and politics (Mozaffari, 2008: 6).

\subsection{Muhammad Abduh Discourse, The Link between Religion and Politics}

Muhammad Abduh was an Egyptian thinker and reformer and Sayyid Jamal al-Din Asadabadi's student, and tried to defend the Islam with reformative thinking considering the time circumstances. He considered internal despotism and external colonialism among the most important causes of backwardness of Muslims. In his view, the law and wisdom are in harmony, and the problem of fixity and variable and dynamics of discretion are keys to Muslim nations. Abduh saw a deep relationship between religion and politics and was seeking to reform the Ottoman Caliphate. In his view based on the council principle, form of government has been vested in the people and the caliph should not be directly involved in such matters (Abduh, 1936: 87).

\subsection{Muhammad Abduh and Ali Abd Al-Raziq Differences}

Dual-thinking of these two thinkers on the relationship between religion and politics should be probed in the differences in their discourse. The discourse means a set of concepts, rules and statements that makes a different semantic system in the specific structure from other systems. Discourses shape our understanding and conception of reality and have their own distinct identity and classification. This variable has caused differences in their understanding of the nature of religion and politics and their opposite conclusion. In one hand, Mohammad Abduh knew constitutional monarchy as the best government in the present; on the other hand, he did not see people to be prepared for this kind of political system and thought that leader must train people to reach such a stage. According to Rashid Reza, Abduh in the period after the exile due to the same ideas was in dispute with Seyid Jamal, and faulted Seyid Jamal in later years of his life that why he suggests his followers that the only way to attain true independence, maturity and political development is political activity, and once Abdu told one of his disciples: "Seyid nowhere did not something real except in Egypt and what was better that instead of becoming infected with court intrigues in Constantinople, tried to convince the Ottoman sultan to reform the educational system". Abdo was a man of thought and moderate and was more explicit Muslim religious and moral education (Yousefi, 2011: 104). Considering the circumstances and problems of Abdo time, it must be said that Abdo's religious and political thought his time was to respond to his period questions. Among Abdo assumptions to interpret Islam in accordance with the terms and requirements of the day, this is that, first; Islam should not be ignored in confrontation with the West. His second assumption is that Islam is a religion adapted to different times and places and in no way could not imagine that Islam is not compatible with the demands of modern times. Accordingly, Abdo obtains a relatively new approach by means of a specific definition of Islam. He started out as an introduction and foundation of his argument emphasizing of discretion, common sense and reason in religion proves that the religious authoritative is very little in the field of social issues; in fact, political and social affairs of the people were abandoned to their own minds based on the council system. Then he establishes a system in his political thought that individuals' role is enormous and civil society organizations are strong. People legitimize the government with their vote and monitor its actions. Monitoring for people is the right one. If Caliphate system reinstates, it can be a religious government and effective in the fatwa, but political and social issues of their own people to have been granted to them. In general we can say that the crisis theory in social and political thought of Abduh is largely accountable. The crisis of Abduh time was challenges which Islam and Muslims encountered against the demands of modern society. But one of the graduates of Al-Azhar and its scholars, Ali Abd al-Raziq wrote the book "Islam and al principles", blew the strongest impact to the half-life body of caliphate and made such a splash that only it subsided with disappearance of the subject. Abdul expressly claimed that caliphate does not belong to the Islamic principles and has been a result of certain conditions and basically Sheikhs caliphate has not had the religious nature. He put his feet up and claimed that Islam does not have particular government idea and ruling is not dignity of the prophet of Islam, the basic duty of the Prophet is and notification of the prophecy, not its implementation. So religion can be separated from politics without concern (Enayat, 1984: 239). Ali Abd al-Raziq was the first modernist who considered the issue of separation of religion and politics in detail. In his book "Islam and ordinance principles" which was published in 1925, he claimed that a reason or pseudo-evidence of the government and politics is not said in Quran. Abdul, contrary to popular belief of Sunni Muslims, believes that the Caliphate does not belong to the principles of religion and pillars of Shari, in Islam, politics is separate from religion and therefore Muslim nations should 
prevent the Lord of religion to intervene in politics in this era. It should be noted that when this book was published, the issue of abolition of the caliphate in Turkey caused controversy and debate among Sunni Muslims and the ideas set forth in this, theoretically, strengthened and affirmed governance and performance of Ataturk in Turkey and provoked Al-Azhar scholars and Egypt religious community against Abd al-Raziq and brought this secular writer to trial and dismissal of the judge and his rejection by the religious community of Egypt. In addition, his book was refutation for the book of Mohammad Rashid Reza about caliphate, i.e. "caliphate and grand Imam". He denies the relationship between religion and politics in general and announced the Qur'an strategies are non-politic and also denied the Prophet (pbuh) government. Although Abdul began with the rejection of government and was seeking to approve the abolition of the Ottoman Caliphate, but he wasn't satisfy of this and declared disputable verses and hadiths that have been used to prove the necessity of Imam and Caliph and considered legitimate relationship between religion and politics through them and justified them and determined them weak on the basis of reference and document (Abdul Raziq, 2004: 86). It is worth to note that Abdel fluctuates between secularism and to accept relationship between religion and politics and the rejection of theocracy and because his major opinion was negation of the Caliphate in Islam. Some of his evidences will never lead to prove the separation of religion from politics, but on the whole, he is one of the most prominent Islamic scholars in the field of "erudition" and secularism thought, as this thought, particularly after the Islamic Revolution, has reflected among Iranian thinkers in different degrees and have found supporters and claimants and some have made speech about, on the contrary to the theory of religious government, non-religious state or a secular state (Firahi, 2004: 25). According to Abduh, what was necessary to reform the Muslims was to reinterpret Islamic law for the implementation of time issues with them. In practice, such an interpretation was impossible without changing some principles of the Sharia, but who had the capacity and the courage to change? It was here that the need to restore religious powers and duties of Khalifa and Muslims ruler was obvious. Abduh, like other Arab reformers, had caught between two incompatible dreams: One dream was political unity of the Muslim nations that not only would encompass Egyptians but also Muslims around the world and secondly, the desire for the unity of Egypt nation which were, however, only a branch of the Muslim nation. Abduh has never defended "erudition" and of his true disciple, Mohammad Reza Rashid, was one of the Caliphate defenders in its old form. This idea was stated emphatically by one of the sheikhs from Al-Azhar, indicates the basic principles of government in Islam, as Abduh thinks, and do not reflect the real behavior and history of Sunni caliphs in most historical periods that have done just the opposite of what Abduh wished and determined obedience to the caliphate a religious duty of Muslims in all circumstances and Sunni scholars and dogmatists also endorsed their deception. Abduh, with all his sincerity against Islamic Sharia, was a patriotic man and sometimes his patriotic mixed and appeared with enthusiasm that his attachment would conflict to the unity and equality of all Islamic nations. In the first article in the newspaper "Al-Ahram", he praised the ancient Egyptian civilization and expressed this conviction in most of his writings that those who have a history and common land, in spite of ideological and religious differences, are endowed with a lasting friendship implantation (Enayat, 2010: 87). Muhammad Abduh and Ali Abdel-Raziq, respectively, represented the two types of attitudes about the role of politics and government in Islamic thought and literature. Although Abduh's ideas among Muslims were considered conventional and classic ones, but the discussions that Ali Abdel raised in "al-Islam and the principles of al-hekam" (1925), were unconventional and controversial for many Muslim thinkers. While Muhammad Abduh emphasized on the legitimacy of government in Islam, especially in the tradition of the Prophet (PBUH) and the consensus of the Muslims, knew caliphate the only form of legitimate government for Muslims, Ali Abd al-Raziq in his book insisted on the fact that the Koran, the Sire of the Prophet (PBUH) and the consensus do not indicate legitimate evidence for the caliphate system as a system of government is not obligatory for Muslims. According to him, the caliphate has not come in the governmental system concept in Quran, but it points to non-political replace and spiritual follow of the commandments of God and Islamic ethics. He knew the Prophet of Islam (PBUH) action to establish government in Medina, not the result of divine revelation, but from the Prophet wisdom to handle Muslims life and the need to defend Muslims against unbelievers. According to Abdu al-Raziq, the caliphate system was nothing but a blow to the reputation of Islam and to put pressure on people. Ali Abdel considered theocracy as a cover for continuing the reign and in this regard even he opposed to Ibn Khaldun who distinguished between the monarchy and caliphate. Although Ali Abdel lived alone until his death (September 1966) and his book was prohibited to publish, But his thoughts were followed to debate on incorrect or correct his arguments. Although the original context of Al-Azhar scholars and political Islamists continued to oppose his views, but in the Arab world during the 1970s, gradually those rose to defense his positions and arguments. "Mohamed Amara", Egyptian writer, believes that Abdul al-Raziq thought was "the development of Muhammad Abduh ideas" because Abduh, the great Islamic reformer before Abdul Al-Raziq, considered the divine legitimacy aspects of the Caliph unfounded and emphasized to exercise people control over Khalifa. 
According to Abdo, " people have the right to control (the Caliph), and can depose Khalifa to be in his favor at any time, because the Khalifa is a civil ruler in every respect." (Amara, 1972: 34). Religion and its orders have always regulated Muslim societies' social and political life. The first encounters of Muslim world with the civilization of the West and to understand the phenomenon of underdevelopment in these communities provoked different theoretical and practical reactions in the Muslim thoughtful, each tried to find their way to release the current situation. In such spectral range, Muhammad Abduh and Ali Abdu al-Raziq, were representatives of two influential streams of thought in the Middle East and somehow each were trying to discover progress possibility in the Muslim community by analyzing the fundamentals of Islam and considering the requirements of new era. In fact, where Abdul rejected common Islamic theocracy under historical conditions of Muslim communities, Abduh believed in way to overcome the crisis caused by exposure to Western colonialism would depend on the Islamic state establishment. Although it seems that the ideas of these two thinkers have difference or even the principal contradiction in dealing with the relationship between religion and politics, but, in fact both thinkers emphasize the role of human agency in social self-determination. Sheikh Muhammad Abduh believed in confrontation with the West that we should return to real Islam, that if it happens, will solve all the problems of the Muslim community. He said Islam that was located in current day society, it is not Islam, but is to maintain the appearance for prayer, fasting and pilgrimage. And except for a brief speech, all of speeches have been away from their meaning and have been turned upside down, and as a result, of what occurred innovations and superstitions in Islam, Muslim people have come to the current stagnation that consider it a religion (Abdo, Beata: 95).

\section{Conclusion}

A glance at the history of the Muslim life from early Islam to contemporary period shows that Muslims had certain political system over the centuries that were based on the orders of Islamic Sharia. In this system, the sovereignty and power are of God and the caliphs, governors and kings (at least in appearance) were forced to enforce Islamic law. In fact, Muslims, before the confrontation with modern political ideas, did not have conceptual equivalent for secular and secularism. In modern times and after the Muslim were familiar with the developments of modernity in the West, willingly or unwillingly, it was suggested to them whether they should cut the relationship between the religion and politics like the Christians. In this regard, an overview of the ideas of Muslim scholars suggests that they are responding to this trend are two broad groups. The first group believes that Islam is the religion of all present and future generations of mankind and in which all the needed principles for human life, including the principles of the government, are expressed. The second category advocates the implementation of secularism in the Muslim world that and have tried to distance Islam, like Christianity, from politics. Egyptian Ali Abdul al-Raziq was one of the most important representatives of the pro-separation of religion and government among Sunni scholars that made clear his opinions in the book "Islam and principles". In addition to deny the necessity of the theory, he spoke about the secularism and the necessity of not having to set up an Islamic state. According to him, the caliphate does not have the religious foundation, even the first caliph came to power in the political process and gave his government a religious attribute, the next caliphs tried to promote this doctrine that caliphate is a religious duty with the aim of increasing their dominance and power. According to Ali Abdo al-Raziq, Islam has left the politics to humans to use reason and rational latest achievements and consistent experience of the nations to determine the form of government in regard to their circumstances. To review Abuo al-Raziq ideas, it should be noted that the secularism in his look does not reflect a rejection of the political status of the Prophet of Islam, but it seems that he looked into this matter liberally and questioned the necessity of the caliphate. Abdul believes that "there is no doubt that there are cases in prophetic state which are similar to the manifestation of political government", this means that he accepts the Prophet state, but sees it as a kind of civil government, not theocracy. Unlike him, Sheikh Muhammad Abduh, as a theoretician and Islamic modernists, had focused all his reformative thoughts and ideas on the Islamic rationalism and moralism, therefore, a number of Sunni scholars have considered him the founder of new movement of Mu'tazilite. In the Muslim world, he is known more as a religious and moralist reformer than a political reformer. In his view, the main reason for Muslim weakness and degeneration is caused by the penetration of deceitfulness and misunderstandings that have appeared in their intellectual, political and religious principles which has brought religious superstitions and heresies. He politically believed that caliphate should belong to Arabs and must resist against imposing Turkish policies against Arabs and Ottoman Turks rule over Egypt. In his opinion, the Islamic ruler, Mufti, priest authority and so on has civil attribute not religious, and their religious privileges does not arise from religion, but the religion defines the degree of their duties and authority. This is not due to the separation of religion and politics, but also to avoid the Caliph and Mufti religious tyranny and religious domination is only for Allah and His Messenger. The best form of government from Abdu's perspective is constitutional monarchy (parliamentary democracy). Provided that it causes progress towards improving the 
nation's religious, moral, and political conditions and if it was an obstacle to its government, it should be determined as wrong or at least premature state and if it is tyranny government or even alien to help meeting this goal should be tolerated. Sheikh Muhammad Abduh, among Sunnis, especially among the Arabs after Jamal, is known the second reformer. He is not only one of the characters to start reformative movements, but the impact of his works and ideas surrounded Islamic world, especially Morocco, Algeria, Tunisia, Morocco, Syria, Sham, Lebanon, Palestine, , the Indian subcontinent, Iraq and Iran. No wonder, if Abdu's political ideas as well as his views on religious and moral issues are not clear and uncluttered and quester forces to extract them out discretely among his writings and words.

\section{References}

Abdo, M. (1936). a treatise al-Tawhid. Beirut: Darahya'allvm.

Abdul al-Raziq, A. (1999). Islam and the principles of orders, margins and suspension of Dr. Mahmoud Haqi. Tehran: Amir Kabir.

Abdul al-Raziq, A. (2003). Islam and Principles of Government. Translated by Mohammad Taghi Mohammadi and Mohtaram Rahmani, Tehran: Sarahy Publications.

Akhavan Kazemy, B. (2006). The review and evaluation of secularist altitude to the Prophet's government. Journal of the Islamic government specialized for thought and political jurisprudence of Islam, 11(4).

Amara, M. (1972). Islam and principles of orders by Ali Abul al-Raziq. Beirut.

Amid Zanjani, A. (1994). Political jurisprudence (Vol. I). Tehran, Amir Kabir Publications.

Amid Zanjani, A. (1998). The political jurisprudence "the political system and leadership in Islam" (4th ed.). Tehran, Amir Kabir Publications.

Ashary Qomi, Sa'd ibn-Abdullah. (2003). The history of Shiite ideas and sects. Translated by Yousef Fazaee. Tehran: Publication of the book's Nest.

Ashtaraus, L. (1994). What is political philosophy? Translated by Farhang Rajaie, Tehran, Cultural and Scientific Publications.

Bashiriyeh, H. (1997). The history of political ideas of the twentieth century, Marxist political ideas. Tehran: Reed Publishing.

Enayat, H. (1984). To consider Arab political thought. Tehran: The Pocket Book Organization.

Enayat, H. (2010). To consider Arab political thought from Napoleon's invasion to Egypt until World War II, VII. Tehran: Amir Kabir Publication.

Fawzi, Y., \& Karimi Beiranvand, M. (2010). To study the difference between the goals of secular governments and Islamic rule. Political Science Quarterly, (51).

Fyrahi, D. (2004). The political system and government in Islam. Tehran: Samt Publication.

Gorji, A. (2006). The history of jurisprudence and jurists. Tehran: Samt Publication.

Javadi Amoli, A. (1989). The role of Imam Khomeini in the reconstruction of the Imamate. The universe of thought magazine, (24).

Maqsoodi, M., \& Heidari, S. (2011). To examine the similarities and differences between Arabic movements in the Middle East. Journal of policy doctrine, (II).

Modaresi tabatabaee, S. H. (2005). School in evolution process. Darwin Publication.

Mozaffari, A. (2008). The reason of antithetical look at the relationship between religion and politics by Egyptian Abdel-Raziq and Imam Khomeini. Islamic Revolution Studies Journal, (15).

Qaderi, H. (1999). Political thought in Islam and Iran. Samt Publication.

Qaderi, H. (2004). Developments, the basis of on the legitimacy of the Abbasid caliphate from start to collapse. Tehran: Bonyan publication.

Qeisari Roomi, M. D. (1996). To explain Fusus al-Hikam. Edited by Syed Jalaluddin Ashtiani. Tehran, Scientific and Cultural Publishing Company.

Yazdanpanah, M. (2011). Islamic Awakening. Tehran: Ministry of Science, Research and Technology, Cultural and Social Department.

Yousefi, B. (2011). To review and interpret Seyid Jamal-al-din Assadabadi and Muhammad Abduh view in the 
course of transcendental Islamic awakening, contemporary political essays. Institute for Humanities and Cultural Studies, (II).

\section{Copyrights}

Copyright for this article is retained by the author(s), with first publication rights granted to the journal.

This is an open-access article distributed under the terms and conditions of the Creative Commons Attribution license (http://creativecommons.org/licenses/by/4.0/). 